\title{
EXPERIENTIAL MARKETING TERHADAP CUSTOMER VALUE DAN CITRA SERTA PEMBELIAN ULANG
}

\author{
Rusna Purnama \\ rup@stp-bandung.ac.id \\ STP Bandung \\ Jl. Dr. Setiabudi No.186, Hegarmanah, Kec. Cidadap, Bandung, Jawa Barat 40141
}

diterima: 28/12/2019; direvisi:4/2/2020; disetujui: 27/2/2020

\begin{abstract}
This study aims to determine the effect of experiential marketing on customer value and corporate image as well as its implications on the repurchase interest of cafe \& restaurant visitors in Bandung. The research method used is descriptive and verification analysis. Data collection used was interviews using a questionnaire accompanied by observation and literature techniques, sampling techniques using consecutive sampling with a sample of 100 respondents. Data collection in the field was carried out in 2019. Data analysis techniques used Path Analysis. The results show that in general experiential marketing falls into the good category as well as customer value while the image and interest in repurchase tend to be sufficient. Experiential marketing influences customer value and company image and customer value and company image influences repurchase interest.
\end{abstract}

Keywords: corporate image; customer value; experiential marketing; repurchase interest

\begin{abstract}
Abstrak
Penelitian ini bertujuan untuk mengetahui pengaruh experiential marketing terhadap customer value dan citra perusahaan serta implikasinya pada minat pembelian ulang pengunjung cafe $\&$ resto di Kota Bandung. Metode penelitian yang digunakan adalah analisis deskriptif dan verifikatif. Pengumpulan data yang digunakan adalah wawancara dengan menggunakan kuesioner disertai dengan teknik observasi dan kepustakaan, teknik pengambilan sampel menggunakan consecutive sampling dengan sampel berjumlah 100 responden. Pengumpulan data di lapangan dilaksanakan pada tahun 2019. Teknik analisis data menggunakan Analisis Jalur. Hasil penelitian menunjukan bahwa secara umum experiential marketing masuk dalam kategori baik begitu juga customer value sedangkan citra dan minat pembelian ulang cenderung cukup. Experiential marketing berpengaruh terhadap customer value dan citra perusahaan serta customer value dan citra perusahaan berpengaruh terhadap minat pembelian ulang.
\end{abstract}

Kata Kunci: citra perusahaan; customer value; experiential marketing; minat pembelian ulang 


\section{PENDAHULUAN}

Perkembangan dunia usaha saat ini, masih banyak negara yang sumber pendapatannya bergantung pada sektor industri pariwisata. Termasuk Indonesia, dimana negara ini adalah salah satu negara yang mendapatkan pemasukan devisa paling besar yang berasal dari kegiatan pariwisata. Sehingga setiap perusahaan di bidang jasa dan industri, terutama pariwisata saling berkompetisi untuk menarik para wisatawan domestik maupun wisatawan mancanegara agar datang ke wilayah Indonesia. Agar dapat menambah pemasukan devisa bagi Indonesia, khususnya wilayah yang dikunjungi oleh para wisatawan.

Sesuai dengan Undang-Undang No. 10/2009 tentang Kepariwisataan, yang dimaksud dengan pariwisata adalah berbagai macam kegiatan wisata yang didukung oleh berbagai fasilitas serta layanan yang disediakan masyarakat, pengusaha, Pemerintah dan Pemerintah Daerah. Pariwisata dikelompokkan ke dalam industri jasa, dimana kegiatan ini termasuk menangani jasa mulai dari transportasi, jasa keramahan, tempat tinggal, makanan \& minuman, dan berkaitan dengan jasa lainnya seperti Bank, Asuransi keamanan dan lain-lain.

Industri pariwisata di Indonesia semakin berkembang pesat seiring dengan majunya pertumbuhan ekonomi dunia dan adanya kemudahan akses informasi yang tersedia. Hal tersebut dapat menarik para wisatawan mancanegara untuk datang dan menikmati keanekaragaman budaya, seni, serta alam Indonesia, yang dapat mendukung dalam perkembangan pariwisata. Dengan adanya aktifitas pariwisata ini telah membuka pandangan masyarakat terhadap potensi pariwisata yang amat besar, salah satu cara untuk mengurangi pengangguran serta meningkatkan taraf hidup masyarakat sekitar.

Biro Pusat Statistik (BPS) mencatat bahwa pariwisata Indonesia saat ini merupakan sektor terbesar kedua setelah minyak-gas (migas), yang menghasilkan penerimaan devisa mencapai sekitar 4,5 milliar USD dengan kunjungan sebesar 5,321 juta wisatawan mancanegara (wisman). Oleh karena itu, pemerintah memprediksikan sektor pariwisata sampai dengan tahun 2018 dari kunjungan wisman dan wisatawan nusantara (wisnu) rata-rata sebesar $15,69 \%$ per tahun dengan peningkatan penerimaan devisa $1 \%$ peProvinsi Jawa Barat merupakan salah satu provinsi termaju dan mitra terdepan ibukota negara, memprioritaskan sektor kepariwisataan menjadi bagian terpenting dalam pembangunan daerahnya. Dengan posisi sebagai salah satu dari 6 core business Provinsi Jawa Barat, sektor pariwisata diharapkan dapat mendukung peningkatan PAD Jawa Barat.

Kota Bandung merupakan kota pariwisata, selain itu Kota Bandung merupakan surga belanja yang dikenal dengan sebutan Paris Van Java. Paris Van Java telah menjadi satu predikat yang tidak dapat dilepaskan dari
Kota Bandung. Sejarah menyatakan bahwa predikat tersebut diberikan oleh warga Eropa yang bermukim di Indonesia semenjak jaman kolonial Belanda, dan menjadikan Paris Van Java sebagai pusat kegiatan mereka, mulai dari kegiatan intelektual, kesenian, budaya, hingga hiburan dan rekreasiKegiatan wisata yang ada di Kota Bandung begitu bervariasi, sehingga dapat mendorong banyaknya usaha yang bermunculan . Menurut Morrison dalam Isharyanti (2015) terdapat tiga bagian dalam hospitality industry, diantaranya adalah lodging operation, food and beverage service, dan travel/tourism. Industri tersebut merupakan industri yang bersifat memberikan pelayanan jasa terhadap masyarakat, salah satunya ialah dengan adanya akomodasi pariwisata. Selain adanya usaha akomodasi, dalam hospitality industry terdapat food and beverage service yang diantaranya ialah usaha jasa boga yaitu restoran.

Berdasarkan Tabel 1 dapat dilihat bahwa jumlah kunjungan wisatawan ke Kota Bandung meskipun mengalami penurunan pada tahun 2017 ke 2018 tetapi jumlah wisatawan dari tahun ke tahun sangat banyak dan stabil. Banyaknya wisatawan domestik juga dikarenakan adanya akses yang lebih mudah untuk berkunjung ke kota Bandung yaitu adanya fasilitas jalan tol Cipularang yang mulai beroperasi pada 26 april 2005 yang membuat akses menuju kota Bandung menjadi lebih mudah sehingga wisatawan domestik khususnya yang berasal dari Kota Jakarta dan sekitarnya menjadi lebih mudah untuk berwisata ke kota Bandung.

Persaingan di restoran dan cafe sangat ketat, hal ini di akibatkan oleh semakin banyaknya konsumen cafe yang dapat dilihat dari jumlah penduduk Bandung yang terus meningkat dan semakin kuatnya pandangan bahwa Bandung adalah pusat kuliner. Pada saat ini banyak konsumen yang suka menghabiskan waktu di café, hal ini juga menjadi peluang bisnis yang baik untuk memperoleh keuntungan, hal ini ditunjukkan dengan jumlah cafe dan restoran yang semakin meningkat setiap tahunnya. Berikut adalah jumlah cafe di Bandung 5 tahun terakhir.

Pada tahun 2014 sampai dengan tahun 2018 perkembangan café di Bandung terus mengalami peningkatan dan ini menunjukkan bahwa persaingan cafe di Kota Bandung cukup bersaing. Peningkatan jumlah cafe yang ada di Bandung ini diduga terjadi karena para pelaku bisnis cafe melihat peluang menarik yaitu banyaknya para wisatawan yang berkunjung ke Bandung dan juga banyaknya penduduk Bandung yang sangat menjanjikan untuk perkembangan bisnis dibidang kuliner.

Keadaan seperti itu dapat membuka peluang bagi para pengusaha untuk melakukan suatu bisnis makanan. Bisnis makanan pun berkembang pesat di Kota Bandung. Bisnis makanan dipercaya merupakan salah satu dari sekian banyak bisnis yang tidak terlalu terkena imbas krisis. Sebabnya semua orang butuh 
makanan, sehingga otomatis pasti dicari orang. Berbagai komponen yang ada di Kota Bandung, mulai dari jajanan hingga cafe selalu menjadi objek perhatian masyarakat. Di Bandung banyak terdapat rumah makan, cafe, restoran dengan lokasi yang tersebar. Ada yang di bukit sambil menikmati pemandangan, di pinggir kota maupun di pusat kota. Menunya beragam, mulai dari masakan Sunda, Padang, Oriental, Western, Korean, Thailand, Japan dan sebagainya.

Menurut Marsum (2010) pertumbuhan cafe dan restoran di Jawa Barat, khususnya di Bandung menjadi perkembangan yang sangat pesat dibandingkan dengan daerah-daerah lainnya (Tabel 2). Semakin meningkatnya jumlah restoran dan cafe yang ada di Kota Bandung, antara lain disebabkan oleh beberapa hal diantaranya: 1). Sektor bisnis hospitality industry mempunyai prospek yang cerah, bidang ini antara lain mencakup bisnis restoran, cafe, hotel dan pub yang ternyata masih terbuka karena permintaan jasa pariwisata yang ditawarkan Kota Bandung cukup tinggi sehingga kebutuhan terhadap penawaran atas sektor hospitality industry juga mengalami tren yang tinggi, 2). Pola hidup masyarakat juga ikut berubah dimana sekarang banyak orang yang datang ke restoran untuk mencicipi hidangan di restoran dengan beberapa alasan seperti untuk kepentingan bisnis, karena jauh dari rumah atau sekedar bersantai, dan 3). Kebijakan pemerintah yang mendukung iklim investasi dimana kebijakan yang dikeluarkan untuk pengembangan hospitality industry adalah Inpres No. 7/1978, didalamnya dijelaskan bahwa semua proses perizinan telah diatur dalam suatu mekanisme atau ketetapan yang menyangkut jenis perizinan dan retribusi dan memberikan kemudahan bagi para pengusaha untuk mengembangkan bisnis sektor penunjang pariwisata seperti hotel dan resto.

Restoran dan cafe merupakan usaha jasa makanan dan minuman hal ini dijelaskan pada UU 10/2009 disebutkan bahwa yang dimaksud dengan usaha jasa makanan minuman adalah usaha jasa penyediaan makanan dan minuman yang dilengkapi dengan peralatan dan perlengkapan untuk proses pembuatan yang dapat berupa restoran, cafe, jasa boga, dan bar/kedai minum. Peraturan Menteri Kebudayaan dan Pariwisata Nomor PM.87/HK.501/MKP2010 tentang tata cara pendaftaran usaha jasa makanan dan minuman, memberikan definisi bahwa restoran dan cafe adalah usaha penyedia makanan dan minuman yang dilengkapi dengan peralatan dan perlengkapan untuk proses pembuatan penyimpanan dan/atau penyajiannya, di dalam satu tempat yang tidak berpindah-pindah.

Persaingan di restoran dan cafe sangat ketat, hal ini di akibatkan oleh semakin banyaknya konsumen cafe yang dapat dilihat dari jumlah penduduk Bandung yang terus meningkat dan semakin kuatnya pandangan bahwa Bandung adalah pusat kuliner. Pada saat ini banyak konsumen yang suka menghabiskan waktu di café, hal ini juga menjadi peluang bisnis yang baik untuk memperoleh keuntungan, hal ini ditunjukkan dengan jumlah cafe dan restoran yang semakin meningkat setiap tahunnya.

Pada era kompetisi yang semakin ketat ini keberhasilan menciptakan persepsi positif dibenak konsumen merupakan faktor penting dalam kesuksesan penjualan suatu produk, maka dari itu perusahaan perlu menyampaikan atau mengkomunikasikan suatu produk dengan menyentuh sisi emosional konsumen.

Salah satu usaha yang dapat dilakukan adalah menciptakan strategi pemasaran yang berorientasi pada konsumen. Pemasaran yang berorientasi pada konsumen merupakan pemasaran yang menekankan pada pemuasan kebutuhan dan keinginan konsumen. Karena pelanggan yang puas akan memiliki ikatan emosional dengan produk atau jasa yang dikonsumsi dan cenderung menjadi loyal kepada perusahaan.

Salah satu konsep pemasaran yang dapat digunakan untuk mempengaruhi emosi konsumen adalah melalui pengalaman pelanggan, yaitu suatu konsep pemasaran yang tidak hanya sekedar memberikan informasi dan peluang pada konsumen untuk memperoleh pengalaman atas keuntungan yang didapat tetapi juga membangkitkan emosi dan perasaan yang berdampak terhadap pemasaran, khususnya penjualan. Dalam pendekatan ini, pemasar menciptakan produk atau jasa dengan menyentuh panca indera konsumen, menyentuh hati dan merangsang pikiran konsumen. Jika produk dapat menyentuh nilai emosional pelanggan secara positif maka dapat menjadi pengalaman yang tak terlupakan antara perusahaan dengan pelanggan. Hal ini berpengaruh sangat baik bagi perusahaan karena pelanggan yang puas biasanya menceritakan pengalamannya menggunakan jasa suatu perusahaan kepada orang lain

Beberapa peneliti menjelaskan tentang hubungan dan pengaruh pengalaman pelanggan atau experiential marketing terhadap nilai pelayanan dan loyalitas pelanggan, Gentille, et. al. (2012). Dalam pendekatan ini, pemasar menciptakan produk atau jasa dengan menyentuh panca indera konsumen, menyentuh hati dan merangsang pikiran konsumen. Jika produk dapat menyentuh nilai emosional pelanggan secara positif maka dapat menjadi memorable experience antara perusahaan dengan pelanggan. Hal ini berpengaruh sangat baik bagi perusahaan karena pelanggan yang puas biasanya menceritakan pengalamannya menggunakan jasa suatu perusahaan kepada orang lain (Schmitt dalam Rahmawati, 2010).

Schmitt dalam Irawati (2018) menyatakan bahwa dalam memilih produknya, bukan hanya dipengaruhi oleh faktor-faktor rasional saja, tetapi juga faktorfaktor emosional. Faktor emosional ini yang ingin diekplorasi lebih jauh dengan konsep experiential marketing. Pada tahapan experiential marketing ini produsen memandang pelanggan sebagai sosok yang mempunyai nilai emosional yaitu satu pandangan yang 
menekankan adanya hubungan antara produsen dengan pelanggan sampai pada tahap diterimanya pengalaman tak terlupakan oleh pelanggan.

Persaingan bisnis rumah makan sangat ketat, hal ini menuntut para pebisnis yang menggeluti bidang usaha ini. Strategi yang diterapkan tidak hanya berada disekitar kualitas makanan dan minuman, pelayanan dan kenyamanan suasana. Schmitt dalam Andreani (2007) bahwa pengalaman pelanggan dapat dilakukan melalui experience providers (sarana/alat yang memberikan/ menyediakan pengalaman bagi pelanggan). Oleh karena itu setiap restoran dan cafe dituntut untuk menerapkan strategi diferensiasi secara unik, untuk membedakan satu restoran dengan restoran lainnya, dalam upaya menciptakan keunggulan berkesinambungan (Knapp dalam Wibowo, 2011). Faktor penting lain adalah pembentukan identitas, bagi sebuah rumah makan identitas meliputi aspek fisik yang ditampilkan secara khusus dan unik. Oleh karena itulah kunjungan ke rumah makan tidak hanya untuk kebutuhan makan dan minum saja, tetapi juga sebagai wahana rekreasi dan tempat bersantai dengan keluarga, ataupun teman.

Konsep nilai pelanggan mengindikasikan suatu hubungan yang kuat terhadap experiential marketing dari nasabah (Widdis, 2001). Dimana konsep tersebut menggambarkan pertimbangan yang evaluatif nasabah tentang produk yang mereka konsumsi. Nilai yang diinginkan nasabah terbentuk ketika mereka membentuk persepsi bagaimana baik buruknya suatu produk dimainkan dalam situasi penggunaan. Mereka mengevaluasi pengalaman penggunaan pada atribut yang sama, seperti telah dijelaskan diatas bahwa atribut yang dimaksud disini adalah merk dan keunggulan layanan atas produk. Nilai yang diterima bisa mengarahkan secara langsung pada experiential marketing. Experiential marketing sebenarnya lebih dari sekedar memberi peluang pada nasabah untuk memperoleh pengalaman emosional dan rasional dalam memberikan penilaian atas manfaat produk atau jasa yang dirasakannya (Widdis, 2001).

Sementara Kao, et. al. (2007) membuktikan bahwa experiential marketing memberikan dampak positif terhadap customer value dipihak pelanggan. Penelitian yang beliau lakukan terhadap pelanggan Starbucks membuktikan bahwa customer value dapat dibentuk oleh experiential marketing.

Melanjuti teori mengenai customer value di atas Gallarza, et. al. (2011) mengutarakan bahwa value didapat dari interaksi di antara jasa dan penggunanya dan dapat berbeda-beda bagi sesama pelanggan jasa. Interaksi yang cukup kuat akan menciptakan customer value yang kuat juga sehingga akan mendorong respons positif dalam bentuk intensi atau minat untuk meningkatkan frekuensi dan volume pembelian.

Wibowo (2011) menyatakan bahwa inti dari Experiential Marketing adalah membangun hubungan yang langgeng dengan pelanggan. Hal ini juga diperkuat pendapat Schmitt dalam Kustini (2012) bahwa sensori yang terdapat dalam sense, feel, think, act, dan relate, diyakini akan lebih efektif bagi pelanggan, karena sensori tersebut dapat memberikan pengalaman jiwa yang luar biasa. Pelanggan tidak hanya tertarik pada fungsi produk atau jasa, melainkan lebih dalam lagi yaitu pengalaman jiwa yang masuk kedalam produk atau jasa tersebut. Salah satu tindakan yang dapat dilakukan restoran dan cafe dalam memberikan memorable experience kepada pelanggannya adalah dengan mengadakan pendekatan personal yang dapat membentuk pengalaman yang unik dan positif. Pelanggan yang terkesan dengan konsep produk yang telah ditawarkan, atau produk itu memberikan pengalaman positif yang tak terlupakan, maka akan selalu mengingat produk tersebut dan menjadi fanatik dengan produk yang telah dibelinya.

Experiential marketing memberikan informasi dan peluang pada nasabah untuk memperoleh pengalaman atas keuntungan yang didapat dari produk atau jasa itu sendiri tetapi juga membangkitkan emosi dan perasaan yang berdampak pada loyalitas nasabah (Andreani, 2007).

Pelanggan yang tidak merasakan nilai yang lebih dari sebuah produk atau jasa yang ditawarkan, maka akan berpindah ke perusahaan lain yang memberikan nilai yang lebih tinggi atau akan terjadi customer migration. Oleh sebab itu Kotler dan Keller (2016) menyatakan bahwa nilai pelanggan superior (superior customer value) adalah kunci menciptakan loyalitas. Sependapat dengan hal tersebut Dube et.al (2003) menyatakan bahwa dengan menciptakan nilai pelanggan setiap hari akan meningkatkan loyalitas.

Penelitian yang dilakukan oleh Gaffar (2012) mengenai pengaruh hubungan pelanggan dan hubungan masyarakat terhadap nilai dan dampaknya terhadap loyalitas menujukkan bahwa nilai yang dirasakan oleh pelanggan yang terdiri dari nilai pelayanan, produk, citra dan waktu berpengaruh terhadap loyalitas pelanggan.

Konsep nilai konsumen mengindikasikan suatu hubungan yang kuat terhadap experiential marketing dari konsumen (Widdis, 2001). Dimana konsep tersebut menggambarkan pertimbangan yang evaluatif nasabah tentang produk yang mereka konsumsi. Nilai yang diinginkan konsumen terbentuk ketika mereka membentuk persepsi bagaimana baik buruknya suatu produk dimainkan dalam situasi penggunaan. Mereka mengevaluasi pengalaman penggunaan pada atribut yang sama, seperti telah dijelaskan diatas bahwa atribut yang dimaksud disini adalah merk dan keunggulan layanan atas produk. Nilai yang diterima bisa mengarahkan secara langsung pada experiential marketing. Experiential marketing sebenarnya lebih dari sekedar memberi peluang pada konsumen untuk memperoleh pengalaman emosional dan rasional dalam memberikan penilaian atas manfaat produk atau jasa yang dirasakannya (Widdis, 2001).

Sementara Kao, et. al. (2014) membuktikan bahwa 
experiential marketing memberikan dampak positif terhadap customer value dipihak pelanggan. Penelitian yang beliau lakukan terhadap pelanggan Starbucks membuktikan bahwa customer value dapat dibentuk bentuk oleh experiential marketing.

Melanjuti teori mengenai customer value di atas Gallarza, et. al. (2011) mengutarakan bahwa value didapat dari interaksi di antara jasa dan penggunanya dan dapat berbeda-beda bagi sesama pelanggan jasa. Interaksi yang cukup kuat akan menciptakan customer value yang kuat juga sehingga akan mendorong respons positif dalam bentuk intensi atau minat untuk meningkatkan frekuensi dan volume pembelian,

Susanto dan Wijanarko (2004) menyatakan citra akhirnya akan menjelma menjadi sebuah keyakinan berlandaskan nilai yang terkandung dalam citra perusahaan tersebut. Kinerja citra perusahaan akan berkaitan dengan kemampuannya untuk memberikan hal yang menarik bagi pelanggan, dan timbulnya loyalitas merek akan memberikan kontribusi yang sangat berarti bagi perusahaan. Citra perusahaan terutama terbentuk oleh pengalaman pelanggan dalam berhubungan dengan perusahaan, yang diwakili oleh merek dan ditopang oleh organisasi yang berada di belakangnya, serta dijembatani oleh brand promise. Selanjutnya Susanto dan Wijanarko (2004) mengungkapkan bahwa kultur citra yang tercipta dalam masyarakat akan membentuk pola perilaku yang konsisten dan sesuai dengan brand promise. Perilaku yang konsisten ini akan dirasakan sebagai pengalaman merek oleh pelanggan dan akan membentuk citra perusahaan di mata mereka.

Berdasarkan kerangka pemikiran, maka paradigma penelitian pengaruh experiential marketing terhadap customer value dan citra serta implikasinya pada minat pembelian ulang dapat dilihat pada Gambar 1.

\section{METODE}

Penelitian yang digunakan dalam penelitian ini ditinjau dari tujuan penelitian digolongkan sebagai penelitian deskriptif dan verifikatif. Penelitian deskriptif adalah penelitian yang dilakukan untuk mengetahui nilai variabel mandiri, baik satu variabel atau lebih tanpa membuat perbandingan, atau menghubungkan dengan variabel yang lain yang diteliti dan di analisis sehingga menghasilkan kesimpulan. Sedangkan penelitian verifikatif adalah suatu penelitian yang ditujukan untuk menguji teori, dan penelitian akan mencoba menghasilkan informasi ilmiah baru yakni status hipotesa, yang berupa kesimpulan apakah suatu hipotesa diterima atau ditolak.

Dalam penelitian ini ada dua pokok variabel yang akan diteliti, yaitu variabel $\mathrm{X}, \mathrm{Y}$ dan variabel $\mathrm{Z}$. Jumlah sampel untuk penelitian ini adalah sebanyak 100 responden. Teknik analisis data menggunakan metode analisis jalur digunakan untuk menganalisis pada hubungan antar variabel dengan tujuan untuk mengetahui pengaruh langsung maupun tidak langsung seperangkat variabel bebas (eksogen) terhadap variabel terikat (endogen).

\section{HASIL}

Rekapitulasi jawaban memberikan nilai rata-rata experiential marketing sebesar 3,37 dengan persentase $68 \%$, yang berarti experiential marketing pada Cafe $\&$ Resto di Kota Bandung yang terdiri dari dimensi experiential moduls dan experiential providers diinterpretasikan dalam kriteria baik.

Nilai rata-rata customer value sebesar 3,46 dengan persentase $69,16 \%$, yang berarti customer value pada Cafe \& Resto di Kota Bandung yang terdiri dari dimensi customer benefits dan customer cost diinterpretasikan dalam kriteria baik.

Nilai rata-rata citra sebesar 3,31 dengan persentase $66,25 \%$, yang berarti citra Cafe \& Resto di Kota Bandung yang terdiri dari dimensi kesadaran akan citra perusahaan (recognition), kesetiaan/pengenalan citra perusahaan (reputation), kesan kualitas (afinity), dan asosiasi-asosiasi merek (domain) diinterpretasikan dalam kriteria cukup baik.

Nilai rata-rata minat pembelian ulang sebesar 3,27 dengan persentase $65,40 \%$, yang berarti minat pembelian ulang pelanggan pada Cafe \& Resto di Kota Bandung yang terdiri dari dimensi kemungkinan membeli produk lagi, kemungkinan mencoba produk lagi, dan keinginan membeli produk lagi diinterpretasikan dalam kriteria cukup.

Berdasarkan hasil perhitungan statistik, dapat dikatakan bahwa masing-masing variabel yaitu experiential marketing berpengaruh terhadap customer value, dan citra perusahaan serta customer value dan citra perusahaan berpengaruh terhadap minat pembelian ulang, dimana Hasil perhitungan menunjukan bahwa pengaruh experiential marketing terhadap customer value sebesar 58,70\% (Tabel 3). Pengaruh experiential marketing terhadap citra sebesar 59,00\% (Tabel 4). Pengaruh customer value terhadap minat pembelian ulang sebesar $30,20 \%$. Pengaruh citra perusahaan terhadap minat pembelian ulang sebesar $12,80 \%$ dan pengaruh tidak langsung antara experiential marketing terhadap minat pembelian ulang melalui customer value adalah sebesar 72,33\%. Hal ini menunjukkan bahwa pengaruh tidak langsung experiential marketing terhadap minat pembelian ulang melalui customer value lebih besar dibandingkan dengan pengaruh langsungnya.

\section{PEMBAHASAN}

Hasil analisis deskriptif menunjukkan bahwa secara umum experiential marketing masuk dalam kategori baik begitu juga customer value sedangkan citra dan minat pembelian ulang cenderung cukup. 
Pada dasarnya jawaban respoden terhadap seluruh item pernyataan yang ada sebagian besar menjawab dengan skor diantara 3 sampai dengan 4. Hal ini menandakan bahwa responden menjawab dengan kriteria cukup dan baik, serta respon dari responden cukup positif atau responsif. Dengan demikian bahwa rata-rata penilaian dari seluruh responden terhadap seluruh item pernyataan memberikan penilaian yang baik. Namun demikian masih ada beberapan responden yang menjawab skor 1 dan 2. Hal ini menandakan respon terhadap berbagai item pernyataan belum baik.

Experiential marketing pada Cafe \& Resto di Kota Bandung. Rekapitulasi jawaban memberikan nilai rata-rata variabel experiential marketing sebesar 3,37 dengan persentase $68 \%$, yang berarti experiential marketing pada Cafe \& Resto di Kota Bandung yang terdiri dari dimensi experiential moduls dan experiential providers diinterpretasikan dalam kriteria baik. apabila dibandingkan antara dimensi, maka dimensi experiential provider memberikan gambaran yang paling baik sedangkan dimensi experiential moduls memberikan gambaran yang paling rendah. Nilai rata-rata tertinggi berada pada indikator mengenai nama/merek Cafe \& Resto Unik, serta terdapat komunitas pelanggan di Cafe $\&$ Resto ini sedangkan nilai rata-rata terendah berada pada indikator mengenai promosi yang disampaikan melalui Brosur, Koran, Majalah, dll kurang jelas jelas, ruangan Cafe \& Resto kadang kurang harum, serta suasana ruangan, desain eksterior dan interior Cafe \& Resto kadang terasa kurang nyaman.

Customer value pada Cafe \& Resto di Kota Bandung. Rekapitulasi jawaban memberikan nilai rata-rata variabel customer value sebesar 3,46 dengan persentase $69,16 \%$, yang berarti customer value pada Cafe \& Resto di Kota Bandung yang terdiri dari dimensi customer benefits dan customer cost diinterpretasikan dalam kriteria baik. apabila dibandingkan antara dimensi, maka dimensi customer benefits memberikan gambaran yang paling baik sedangkan dimensi customer cost memberikan gambaran yang paling rendah.

Nilai rata-rata tertinggi berada pada indikator mengenai energi yang dihabiskan konsumen untuk datang jauh- jauh ke Cafe \& Resto terbayarkan oleh pelayanan yang diberikan oleh Cafe \& Resto kepada konsumen, dan konsumen merasa bahwa uang yang dihabiskan untuk makan dan berkumpul di Cafe \& Resto sepadan dengan kebahagiaan yang diperoleh sedangkan nilai rata-rata terendah berada pada indikator mengenai kinerja pelayan atau karyawan Cafe \& Resto dalam melayani konsumen cekatan, dan Cafe \& Resto menawarkan berbagai pilihan menu makanan yang sehat untuk dikonsumsi dengan penyajian yang modern.

Citra Cafe \& Resto di Kota Bandung. Rekapitulasi jawaban memberikan nilai rata-rata variabel citra sebesar 3,31 dengan persentase $66,25 \%$, yang berarti citra Cafe \& Resto di Kota Bandung yang terdiri dari dimensi kesadaran akan citra perusahaan (recognition), kesetiaan/pengenalan citra perusahaan (reputation), kesan kualitas (afinity), dan asosiasi-asosiasi merek (domain) diinterpretasikan dalam kriteria cukup baik. Nilai rata-rata tertinggi berada pada indikator mengenai merasa puas dengan pelayanan di Cafe \& Resto sedangkan nilai rata-rata terendah berada pada indikator mengenai nama Cafe \& Resto susah diingat, dan kurang merasa puas dengan produk yang disajikan di Cafe \& Resto.

Minat pembelian ulang pelanggan pada Cafe \& Resto di Kota Bandung. Rekapitulasi jawaban memberikan nilai rata-rata variabel minat pembelian ulang sebesar 3,27 dengan persentase $65,40 \%$, yang berarti minat pembelian ulang pelanggan pada Cafe $\&$ Resto di Kota Bandung yang terdiri dari dimensi kemungkinan membeli produk lagi, kemungkinan mencoba produk lagi, dan keinginan membeli produk lagi diinterpretasikan dalam kriteria cukup.

Berdasarkan hasil uji empiris, diketahui bahwa hasil thitung $(11,801)>$ daripada ttabel $(1,984)$. atau dapat dilihat dari hasil pengolahan menggunakan hasil pengolahan data menggunakan SPSS v. 20.0 yang menunjukan nilai sig t yang sebesar 0.000 dengan $\alpha$ yang lebih kecil dari 5\% sehingga dapat dinyatakan bahwa H0 ditolak. Dengan demikian dapat dinyatakan bahwa experiential marketing berpengaruh terhadap customer value.

Hasil perhitungan menunjukan bahwa pengaruh experiential marketing terhadap customer value Cafe $\&$ Resto di Kota Bandung yaitu sebesar 58,70\%. Hal ini berarti bahwa semakin baik experiential marketing yang diberikan pihak Cafe \& Resto, maka semakin tinggi pula customer value yang diterima pelanggan. Demikian pula sebaliknya bahwa semakin rendah experiential marketing yang dirasakan pelanggan, maka semakin rendah pula customer value yang diterima pelanggan.

Konsep nilai pelanggan mengindikasikan suatu hubungan yang kuat terhadap experiential marketing dari nasabah (Widdis, 2001). Dimana konsep tersebut menggambarkan pertimbangan yang evaluatif nasabah tentang produk yang mereka konsumsi. Nilai yang diinginkan nasabah terbentuk ketika mereka membentuk persepsi bagaimana baik buruknya suatu produk dimainkan dalam situasi penggunaan. Mereka mengevaluasi pengalaman penggunaan pada atribut yang sama, seperti telah dijelaskan diatas bahwa atribut yang dimaksud disini adalah merek dan keunggulan layanan atas produk. Nilai yang diterima bisa mengarahkan secara langsung pada experiential marketing. Experiential marketing sebenarnya lebih dari sekedar memberi peluang pada nasabah untuk memperoleh pengalaman emosional dan rasional dalam memberikan penilaian atas manfaat produk atau jasa yang dirasakannya (Widdis, 2001).

Berdasarkan hasil uji empiris, diketahui bahwa hasil thitung $(6,719)>$ daripada ttabel $(1,984)$. atau dapat dilihat dari hasil pengolahan menggunakan hasil 
pengolahan data menggunakan SPSS v. 20.0 yang menunjukan nilai sig t yang sebesar 0.000 dengan $\alpha$ yang lebih kecil dari 5\% sehingga dapat dinyatakan bahwa H0 ditolak. Dengan demikian dapat dinyatakan bahwa experiential marketing berpengaruh terhadap citra perusahaan.

Hasil perhitungan menunjukan bahwa pengaruh experiential marketing terhadap citra Cafe \& Resto di Kota Bandung yaitu sebesar 59,00\%. Nilai positif ini mengindikasikan bahwa semakin tinggi experiential marketing yang dirasakan pelanggan dalam mengkonsumsi pelayanan, maka citra Cafe \& Resto juga semakin meningkat. Demikian pula sebaliknya bahwa semakin rendah experiential marketing yang dirasakan pelanggan dalam mengkonsumsi pelayanan, maka citra Cafe \& Resto dimata pelanggan juga semakin rendah.

Susanto dan Wijanarko (2004) menyatakan citra akhirnya akan menjelma menjadi sebuah keyakinan berlandaskan nilai yang terkandung dalam citra perusahaan tersebut. Kinerja citra perusahaan akan berkaitan dengan kemampuannya untuk memberikan hal yang menarik bagi pelanggan, dan timbulnya loyalitas merek akan memberikan kontribusi yang sangat berarti bagi perusahaan. Susanto dan Wijanarko (2004) juga mengungkapkan mengungkapkan bahwa citra perusahaan terutama terbentuk oleh pengalaman pelanggan dalam berhubungan dengan perusahaan, yang diwakili oleh merek dan ditopang oleh organisasi yang berada di belakangnya, serta dijembatani oleh brand promise. Selanjutnya Susanto (2014) mengungkapkan bahwa kultur citra yang tercipta dalam masyarakat akan membentuk pola perilaku yang konsisten dan sesuai dengan brand promise. Perilaku yang konsisten ini akan dirasakan sebagai pengalaman merek oleh pelanggan dan akan membentuk citra perusahaan di mata mereka.

Berdasarkan hasil uji empiris, diketahui bahwa hasil thitung $(13,459)>$ daripada ttabel $(1,984)$ sehingga dapat dinyatakan bahwa H0 ditolak. Dengan demikian dapat dinyatakan bahwa customer value berpengaruh terhadap minat pembelian ulang.

Hasil perhitungan menunjukkan bahwa pengaruh customer value terhadap minat pembelian ulang pelanggan pada Cafe \& Resto di Kota Bandung yaitu sebesar $64,90 \%$. Nilai positif ini mengindikasikan bahwa semakin tinggi customer value yang dirasakan pelanggan dalam mengkonsumsi pelayanan, maka minat pembelian ulang pelanggan pada Cafe \& Resto di Kota Bandung juga semakin meningkat. Demikian pula sebaliknya bahwa semakin rendah customer value yang dirasakan pelanggan dalam mengkonsumsi pelayanan, maka minat pembelian ulang pelanggan pada Cafe \& Resto di Kota Bandung juga semakin rendah.

Pelanggan yang tidak merasakan nilai yang lebih dari sebuah produk atau jasa yang ditawarkan, maka akan berpindah ke perusahaan lain yang memberikan nilai yang lebih tinggi atau akan terjadi customer migration. Oleh sebab itu Kotler dan Keller (2016) menyatakan bahwa nilai pelanggan superior (superior customer value) adalah kunci menciptakan loyalitas. Sependapat dengan hal tersebut Dube, et. al. (2003) menyatakan bahwa dengan menciptakan nilai pelanggan setiap hari akan meningkatkan keputusan pembelian.

Berdasarkan hasil uji empiris, diketahui bahwa hasil thitung $(13,034)>$ daripada tTabel $(1,984)$ sehingga dapat dinyatakan bahwa H0 ditolak. Dengan demikian dapat dinyatakan bahwa citra perusahaan berpengaruh terhadap minat pembelian ulang.

Hasil perhitungan menunjukkan bahwa pengaruh citra perusahaan terhadap minat pembelian ulang pelanggan pada Cafe \& Resto di Kota Bandung yaitu sebesar $63.40 \%$. Nilai positif ini mengindikasikan bahwa semakin tinggi citra Cafe \& Resto dimata pelanggan dalam mengkonsumsi pelayanan, maka minat pembelian ulang pelanggan pada Cafe \& Resto di Kota Bandung juga semakin meningkat. Demikian pula sebaliknya bahwa semakin rendah citra Cafe \& Resto dimata pelanggan dalam mengkonsumsi pelayanan, maka minat pembelian ulang pelanggan pada Cafe \& Resto di Kota Bandung juga semakin rendah.

Hasil penelitian dari Bao, et. al. (2010) menemukan bahwa selain pengaruh tidak langsung melalui persepsi kualitas pelayanan, citra perusahaan memiliki pengaruh langsung positif terhadap tindakan pembelian. Selain itu pula menyatakan komponen dari citra perusahaan dapat membuat perusahaan dapat mempengaruhi minat beli konsumen menjadi keputusan pembelian konsumen pada saat melakukan kegiatan berbelanja.

Konsep experiential marketing, perusahaan mencoba melibatkan konsumen melalui emosi (sense), perasaan (feel), mendorong mereka untuk berpikir (think), melakukan tindakan (act), maupun untuk menjalin komunitas (relate). Keberhasilan mengeksekusi lima elemen ini akan membuat merek tertanam lebih dalam dihati konsumen. Cafe \& Resto merupakan salah satu contoh perusahaan dibidang kuliner yang melakukan strategi experiential marketing dalam menarik dan mempertahankan pelanggannya.

Pendekatan experience marketing merupakan salah satu strategi yang dilakukan perusahaan membangkitkan sensasi dan pengalaman yang akan menjadi basis loyalitas pelanggan. Schmitt (2010) berpendapat bahwa pengalaman merupakan suatu peristiwa yang terjadi secara khusus yang dapat merangsang sensory stimuli manusia secara keseluruhan yang disajikan melalui usaha pemasaran sebelum dan sesudah pembelian. Selanjutnya Fodness (2007) menyatakan bahwa pengalaman merupakan peristiwa tersendiri yang terjadi pada orang dalam merespon beberapa stimulus produk.

\section{KESIMPULAN}

Persepsi pelanggan terhadap experiential marketing pada Cafe \& Resto di Kota Bandung yang terdiri dari dimensi experiential moduls dan experiential providers 
diinterpretasikan dalam kriteria baik. Persepsi pelanggan terhadap customer value pada Cafe \& Resto di Kota Bandung yang terdiri dari dimensi customer benefits dan customer cost diinterpretasikan dalam kriteria baik. Persepsi pelanggan terhadap citra Cafe \& Resto di Kota Bandung yang terdiri dari dimensi kesadaran akan citra perusahaan (recognition), kesetiaan/pengenalan citra perusahaan (reputation), kesan kualitas (afinity), dan asosiasi-asosiasi merek (domain) diinterpretasikan dalam kriteria cukup baik. Minat pembelian ulang pelanggan pada Cafe \& Resto di Kota Bandung yang terdiri dari dimensi kemungkinan membeli produk lagi, kemungkinan mencoba produk lagi, dan keinginan membeli produk lagi diinterpretasikan dalam kriteria cukup.

Terdapat pengaruh experiential marketing terhadap customer value sebesar 58,70\%. Pengaruh experiential marketing terhadap citra sebesar 59,00\%. Pengaruh customer value terhadap minat pembelian ulang sebesar 30,20\%. Pengaruh citra perusahaan terhadap minat pembelian ulang sebesar $12,80 \%$ dan pengaruh tidak langsung antara experiential marketing terhadap minat pembelian ulang melalui customer value adalah sebesar 72,33\%. Hal ini menunjukan bahwa pengaruh tidak langsung experiential marketing terhadap minat pembelian ulang melalui customer value lebih besar dibandingkan dengan pengaruh langsungnya.

\section{DAFTAR PUSTAKA}

Ali, J., Mohammad, R.D. and Reza, K.A.M., 2012. Relationship between Manufacturer Product Strategies and Supply Chain Inventory in a Company. Life Science Journal, 9(4).

Andreani, F., 2007. Experiential marketing (sebuah pendekatan pemasaran). Jurnal Manajemen Pemasaran, 2(1).

Bao, Y., Sheng, S. and Nkwocha, I., 2010. Product difficulty incongruity and consumer evaluations of brand extensions. Journal of Retailing and Consumer Services, 17(5), pp.340-348.

Dubé, L., Bel, J.L. and Sears, D., 2003. From customer value to engineering pleasurable experiences in real life and online. Cornell Hotel and Restaurant Administration Quarterly, 44(5-6), pp.124-130.

Fodness, D. and Murray, B., 2007. Passengers' expectations of airport service quality. Journal of Services Marketing.

Gaffar, V., 2007. Customer Relationship Management and Public Relation.
Gallarza, M.G., Gil-Saura, I. and Holbrook, M.B., 2011. The value of value: Further excursions on the meaning and role of customer value. Journal of consumer behaviour, 10(4), pp.179-191.

Gentile, Chiara, Nicola Spiller and Giuliano Noci. 2012. How to Sustain the Customer Experience: An Overview of Experience Components that Cocreate Value with the Customer. European Management Journal. Vol. 25 No. 5 (Mei).

Grönroos, C. and Helle, P., 2010. Adopting a service logic in manufacturing: Conceptual foundation and metrics for mutual value creation. Journal of Service Management, 21(5), pp.564-590.

Isharyanti, N., 2015. Best practices in English teachers Facebook groups. In Proc. Globalization and Localization in Computer-Assisted Language Learning (GLoCALL): Ninth Joint Conference of APACALL and PacCALL.

Kao, Y.F., Huang, L.S. and Yang, M.H., 2007. Effects of experiential elements on experiential satisfaction and loyalty intentions: A case study of the super basketball league in Taiwan. International Journal of Revenue Management, 1(1), pp.79-96.

Kotler, P. and Keller, N., 2016. Marketing management, 5th Global edition. England: Person Education limited.

Kustini, K., 2012. Penerapan Experiential Marketing. Jurnal Riset Ekonomi dan Bisnis, 7(2), pp.44-57.

Marsum,W. A, 2010. Restoran dan segala permasalahannya. Andi Offset.

Rahmawati, 2010. Pengaruh Sense dan Feel dari Experiential Marketing pada Soto Gebrak, Jurnal Ekonomi dan Bisnis, Vol.3 No.2 Agustus hal.109 $-121$.

Schmitt, B. H., 2004. Experiential Marketing: How to Get Customers to Sense, Feel, Think, Act, and Relate to Your Company and Brands. New York: Free Press.

Susanto, A.B. and Wijarnako, H., 2004. Power branding: Membangun merek unggul dan organisasi pendukungnya. Mizan Pustaka.

Wibowo, L.A., 2004. Pengaruh Experiential Marketing dan Emotional Value, terhadap Loyalitas Pelanggan Café dan Resto di Kawasan Cihideung Lembang Bandung. Jurnal Strategic Program Pendidikan Manajemen Bisnis Universitas Pendidikan Indonesia.

Widdis, Peter. 2001. Bringing Brands to Life: Experiential Marketing Works by Touching Consumers Hearts, Marketing Magazine, Toronto Vol. 108 Iss 2 pg. 18. 
Tabel 1. Data Kunjungan Wisatawan ke Kota Bandung tahun 2015-2018

\begin{tabular}{ccccccc}
\hline Tahun & Wisatawan Mancanegara & $\%$ & Wisatawan Domestik & $\%$ & Jumlah Wisatawan & $\%$ \\
\hline 2015 & 685.347 & - & 14.854 .317 & - & 15.539 .664 & - \\
2016 & 676.755 & $(1,25)$ & 19.461 .717 & 31,02 & 20.138 .472 & 29.59 \\
2017 & 530.565 & $(21,60)$ & 15.241 .752 & $(21,68)$ & 15.772 .317 & $(21,68)$ \\
2018 & 529.296 & $(0,24)$ & 16.164 .876 & 6,06 & 16.694 .172 & 5,84 \\
\hline
\end{tabular}

Sumber : Dinas Kebudayaan dan Pariwisata Kota Bandung, (2018)

Tabel 2. Usaha Cafe di Kota Bandung

\begin{tabular}{ccc}
\hline Tahun & Jumlah Café & Persentase Kenaikan (\%) \\
\hline 2014 & 191 & 2,7 \\
2015 & 196 & 2,6 \\
2016 & 235 & 19,9 \\
2017 & 432 & 49,8 \\
2018 & 653 & 51,2 \\
\hline
\end{tabular}

Sumber: Kota Bandung Dalam Angka, 2018

Tabel 3 .

Model Summary ${ }^{\mathrm{b}}$

\begin{tabular}{ccccc}
\hline Model & R & R Square & $\begin{array}{c}\text { Adjusted R } \\
\text { Square }\end{array}$ & $\begin{array}{c}\text { Std. Error of } \\
\text { the Estimate }\end{array}$ \\
\hline 1 & $.766^{\mathrm{a}}$ & .587 & .583 & 1.19335
\end{tabular}

a. Predictors: (Constant), Experiental marketing

b. Dependent Variable: Customer value
Tabel 4.

\begin{tabular}{ccccc}
\multicolumn{5}{c}{ Model Summary } \\
\hline Model & R & R Square & $\begin{array}{c}\text { Adjusted R } \\
\text { Square }\end{array}$ & $\begin{array}{c}\text { Std. Error of } \\
\text { the Estimate }\end{array}$ \\
\hline 1 & $.768^{\mathrm{a}}$ & .590 & .586 & 1.18937
\end{tabular}

a. Predictors: (Constant), Experiental marketing

b. Dependent Variable: Citra

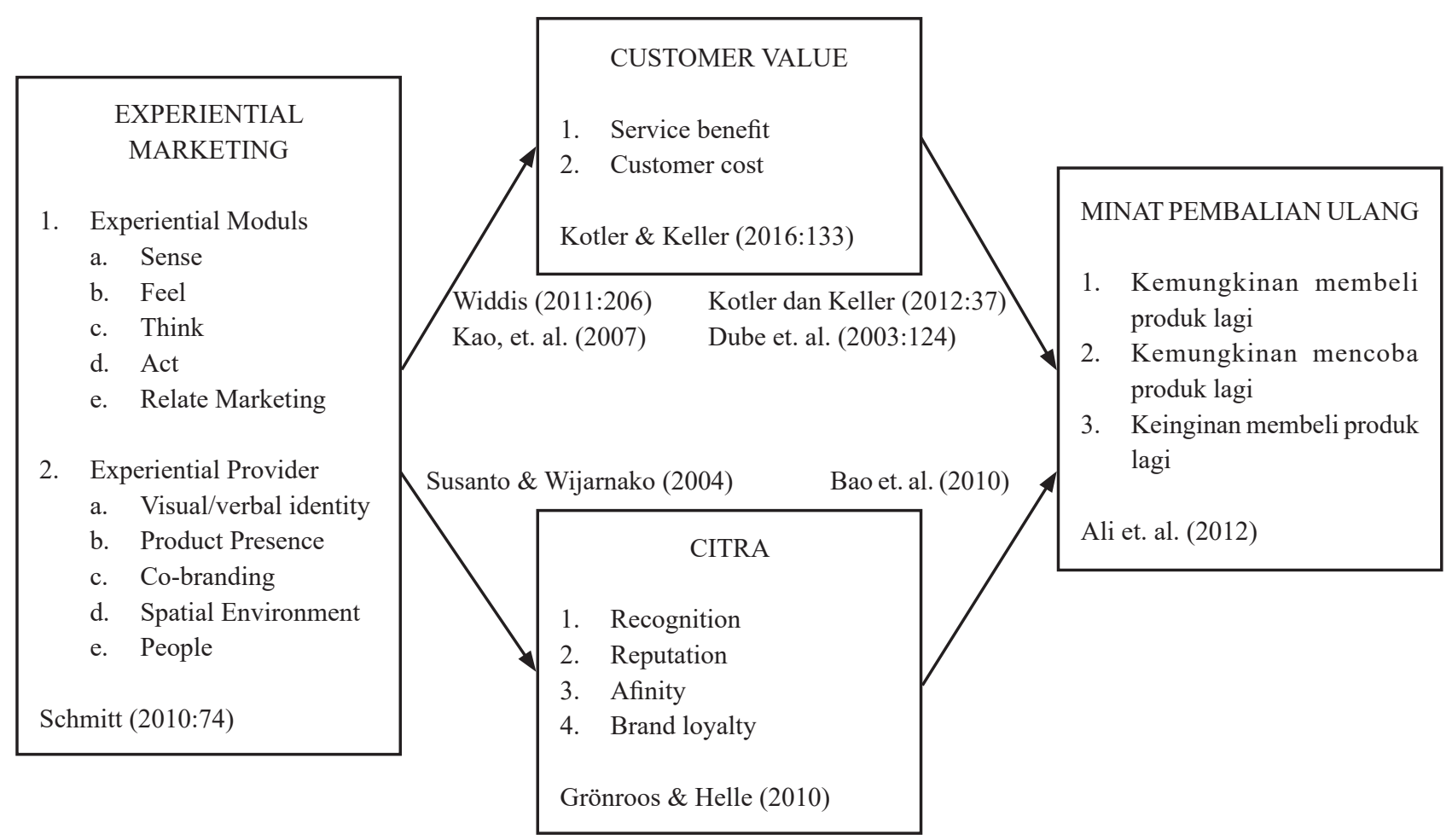

Gambar 1. Kerangka Pemikiran 